\title{
RESEARCH
}

Open Access

\section{Nutritional value and impact of wheatgrass juice (Green Blood Therapy) on increasing fertility in male albino rats}

\author{
Hesham A. Eissa ${ }^{1}$, Sherif S. Mohamed ${ }^{2^{*}}$ (D) and Ahmed M. S. Hussein ${ }^{1}$
}

\begin{abstract}
Background and objective: The wheatgrass juice (WGJ) contains a high concentration of vitamin C. WGJ contains a lot of highly functional nutritive ingredients potent to unify the liver with the kidneys for detoxification of the organs and filtration of the blood to build a strong immune system. Also, it boosts fertility and increases sexual desire because of the high magnesium content in phytochemical pigment (chlorophyll) which boosts the production of the enzymes that restores sex steroids.
\end{abstract}

Materials and methods: The experimental animals were divided into 3 groups of 8 rats. The first group (G1) was fed on the standard normal diet. The same feeding was used also in the second group (G2) and third group (G3). But in the G2, a pharmaceutical formula (contain zinc and vitamin A) was used as a food supplement to increase fertility, and in the G3, wheatgrass juice of $11 \mathrm{mg} /$ day was applied. Hunter $L$, $a$, and $b$ values; glucose, fructose, and sucrose contents; $\mathrm{pH}$; total soluble solids (TSS); acidity; concentration of vitamin C and vitamin B complex contents; and phenolic compounds of wheatgrass quality juice were measured.

Results: The juice samples showed $L^{*}$ value of 21.78 (as a lightness index), $a^{*}$ value of -7.11 (as a redness index), $b^{*}$ values of 17.35 (as a yellowness index), pH (6.7), TSS ( $\left.5^{\circ} \mathrm{Bx}\right)$, and acidity (0.00992\%). In the same time, wheatgrass chlorophyll represents $70 \%$ of its total chemical constituents that is an antioxidant and rebuilds the bloodstream. In addition, it gives the juice its distinctive green color which is the major quality factor in juice products. The results amounted to normal values of vital organs such as the liver and kidney functions in all groups. The values of aspartate aminotransferase (AST) were $27.88 \pm 2.10,22.50 \pm 4.93$, and $23.25 \pm 4.71 \mu / \mathrm{ml}$ in $\mathrm{G} 1, \mathrm{G} 2$, and $\mathrm{G} 3$, respectively. Meanwhile, also the results of sexual hormones indicated an elevation in testosterone hormone in G3 $(2.90 \pm 0.26 \mathrm{ng} / \mathrm{ml})$ than the normal negative control $(2.78 \pm 0.23 \mathrm{ng} / \mathrm{ml})$ and pharmaceutical formula positive control $(2.04 \pm 0.40 \mathrm{ng} / \mathrm{ml})$. However, follicle-stimulating hormone (FSH) decreased to $1.44 \pm 0.28 \mathrm{IU} / \mathrm{L}$ and $1.45 \pm 0.24$ for $\mathrm{G} 3$ and $\mathrm{G} 2$, respectively, compared to $1.65 \pm 0.23 \mathrm{IU} / \mathrm{L}$ in $\mathrm{G} 1$.

Conclusion: The findings proved that WGJ increased fertility and promoted youthfulness, and the wheatgrass (WG) has the potential to be used as a "functional herb" containing natural bioactive compounds.

Keywords: Wheatgrass juice, Nutritional value, Juice quality, Restores fertility, Oxidative stress

\footnotetext{
* Correspondence: shereifsalah@yahoo.com

${ }^{2}$ Nutrition and Food Science Department, National Research Centre, $33 \mathrm{El}$

Bohouth St., Cairo 12622, Egypt

Full list of author information is available at the end of the article
} 


\section{Introduction}

Nowadays, natural or organic bioactive compounds that exist in herbs are considered as an "alternative" medicine. Among herbal and natural active compounds that are gaining scientific concept, wheatgrass (WG) as a "functional food" is becoming more available and popular as a research topic. Wheatgrass is the mature shoot of Triticumaestivum Linn. belonging to the family Gramineae (Rana et al. 2011). Fortunately, wheatgrass considered a high nutritional phytoactive ingredients content that boost alternative medicine value as well as anti-inflammatory, antioxidant, immunomodulatory, anticarcinogenic, laxative, and anti-aging properties, and the use of WG in atherosclerosis, colitis, kidney malfunctions, and swelling has many remedies for many ailments.

Wheatgrass juice (WGJ) can be swallowed orally and as a colon implant without any risk or hazard effects. WGJ is rich in chlorophyll which is an important phytopigment that has an anti-bacterial effect; meanwhile, the chlorophyll of wheatgrass is associated with many health benefits and rebuilds the bloodstream. Studies revealed that animals that intake chlorophyll in the diet are free of any toxic reaction (DeVogel et al. 2005). In the same time, chlorophyll is a potent antioxidant with an effect on cancer prevention. Additionally, selenium and laetrile exist in wheatgrass have anti-cancer activity. Selenium is incorporated as a bioactive natural element that enhances the immune system and can reduce the risk factors of cancer. Wheatgrass comprises of at least 13 vitamins that include B12 and abscisic acid in addition to superoxide dismutase (SOD), cytochrome oxidase, and mucopolysaccharide (Ferruzzia and Blakesleeb 2007; Wheat and Currie 2008).

A normal person should drink $1 \mathrm{fl} \mathrm{oz}(30 \mathrm{ml})$ of fresh wheatgrass juice twice a day or take $3 \mathrm{~g}$ of wheatgrass powder twice a day. A little honey may be added to the juice to enhance the taste. Alternately, approx. $50 \mathrm{~g}$ of fresh wheatgrass could be chewed. Food should not be consumed for half an hour before and after taking wheatgrass. Wheatgrass powder may also be added to regular food as children sometimes may avoid taking it (Grunewald 2009). WGJ is a main source that supplements a lot of nutrients such as iron, calcium, magnesium, amino acids, chlorophyll, bioflavonoids, phenol compounds, and vitamins $\mathrm{A}, \mathrm{B}, \mathrm{C}$, and $\mathrm{E}$ which have an important role in the prevention of various diseases (Peryt et al. 1992; Mujoriya et al. 2012; Sangeetha and Baskaram 2010; Durairaj et al. 2014).

Wheatgrass can be consumed on its own or used in combination with other juices or supplements (Eissa et al. 2018). According to Lani Lopez, a naturopath and the author of the "Natural Health," detoxing and decreasing the oxidative stress of the body before pregnancy can help elevate the fertility and boost a healthy pregnancy. Detoxification is the best process for both men and women as a part of pre-pregnancy care, as purifying internal organs of toxins and oxidative stress can strengthen the body. Drink WGJ daily before pregnancy clean the blood from many toxins (Pannu and Kapoor 2015). The Mayo Clinic reports stated that 15\% of couples are unable to have a child as one or both of them suffer from fertility problems. Diet may also influence the quality of fertility status. In addition to supporting the health and increase body protection, wheatgrass may be potent to boost human fertility due to getting adequate amounts of vitamin $C$ according to the WGJA study defined by Fernandes Glaura (2011) who investigated the vitamin $\mathrm{C}$ effect on hyperglycemic rats and found that it declines the amount of abnormal sperm and raises testosterone in blood. Also, it retrieves fertility and induces a healthy youthfulness because of promoting magnesium content from chlorophyll which is a coenzyme for the enzymes that rejuvenate sex hormones. Moreover, it heightens resistance to ailments by eliminating body toxins, and because of its alkaline properties, it is best for urinal disease.

In the same time, the absorption of such nutrients through the digestive system is necessary. Many people with these deficiencies suffer from cavities and other dental problems even though they brush and floss every day. Brushing and flossing are undoubtedly vital to perfect dental health but cannot be effective unless mineral and vitamin deficiencies are corrected (Sareen et al. 2014)

The objective of this research was to evaluate the nutritional value and quality of WGJ to produce a healthy with vitality function product, high-quality color, and freshness. So, the current research studied the ability and potentiality of WGJ as a functional juice to improve the fertility and sexual potency in male rats. It based on the WG plant rich in bioavailability of multi-active nutrients which have induced fertility and promote youthfulness.

\section{Material and methods Raw materials}

Wheatgrass (Triticum aestivum cv.) obtained from field experimental in the Institute of Agronomy Crops at the Agricultural Research Institute, Giza, Egypt. Wheatgrass samples were used for all processing trials and were stored at $4{ }^{\circ} \mathrm{C}$ after receipt and prepared within $24 \mathrm{~h}$.

\section{Extraction and processing of wheatgrass juice}

In First, the fresh wheatgrass cleaned, soon after cutting it on a pounding basin and crush it well. This wheatgrass can be also crushed in the electric juicer or mixer also. A stainless steel sieve could also be used for this purpose. Second, wrap them in a clean and thin piece of double-layer cheesecloth and strain the juice out of it to 
remove the pulp and obtain the juice, and store at $4{ }^{\circ} \mathrm{C}$ prior to processing and blends. The extraction of wheatgrass juice will be in a greater quantity, and its effectiveness is also strengthened.

\section{Physico-chemical analyses}

The $\mathrm{pH}$ of WGJ was measured using a digital $\mathrm{pH}$-meter (HANNA, HI 902 m, Germany). The percent of total soluble solids (TSS), expressed as ${ }^{\circ} \mathrm{Bx}(0-32)$, was determined with a hand refractometer (ATAGO, Japan). Titratable acidity of juice samples was determined according to the method reported by Tung-Sun et al. (1995).

\section{Color characteristics}

Color of wheatgrass juice was measured using spectrocolorimeter (Tristimulus Color Machine) with the CIELAB color space (International Commission on Illumination) as mentioned by Sapers and Douglas (1987) and Hunter (1975). The color of fresh wheatgrass juice samples was measured using a HunterLab colorimeter Hunter $a^{*}, b^{*}$, and $L^{*}$. Parameters were measured with a color difference meter using a spectro-colorimeter (Tristimulus Color Machine) with the CIE lab color scale (Hunter, Lab Scan XE - Reston VA, USA) in the reflection mode. The instrument was standardized each time with a white tile of Hunter Lab Colour Standard (LX No. 16379): $X=72.26, Y=81.94$, and $Z=88.14 \quad\left(L^{*}=\right.$ 92.46, $\left.a^{*}=-0.86, b^{*}=-0.16\right)$. The instrument $\left(65^{\circ} / 0^{\circ}\right.$ geometry, D25 optical sensor, $10^{\circ}$ observer) was calibrated using white and black reference tiles. The color values were expressed as $L^{*}$ (lightness or brightness/ darkness), $a^{*}$ (redness/greenness), and $b^{*}$ (yellowness/ blueness). The Hue $(\mathrm{H})^{*}$, Chroma $(\mathrm{C})^{*}$, and browning index (BI) were calculated according to the method of Palou et al. (1999) as follows:

$$
\begin{aligned}
& \mathrm{H} *=\tan -1[b * / a *] \\
& \mathrm{C} *=\text { square root of }\left[a_{2} *+b_{2} *\right] \\
& \mathrm{BI}=[100(x-0.31)] 10.72 \\
& \text { Where }-X=\left(a^{*}+1.75 L^{*}\right) /\left(5.645 L^{*}+a^{*}-3.012 b^{*}\right) \\
& \Delta \mathrm{E}=\left(\Delta a_{2}+\Delta b_{2}+\Delta L 2\right) 1 / 2
\end{aligned}
$$

where all values were recorded as the mean of triplicate readings.

\section{Vitamin C determination}

Vitamin C was analyzed using the A.O.A.C. (2006) method. Vitamin $C$ retention was calculated using Eq. (5).
Retention $(\%)=\frac{\mathrm{Mg} \text { ascorbic acid } / 100 \mathrm{~mL} \text { juice after treatment }}{\mathrm{Mg} \text { ascorbic acid } / 100 \mathrm{~mL} \text { juice before treatment }} \times 100$

\section{Sugar determination}

The extraction for determination of sugar acids using high-performance liquid chromatography (HPLC) was achieved by stirring $3.0 \mathrm{~g}$ of each sample with $20 \mathrm{~mL}$ of distilled water, followed by centrifugation at 10,000 g for $10 \mathrm{~min}$ at $30^{\circ} \mathrm{C}$. The residues were washed four times with the same amount of water in order to remove all sugar, and the supernatants were combined. An aliquot of each sample was filtered through $0.22 \mu \mathrm{m}$ Millipore membranes.

For the determining sugars, an Agilent model 1100 Series (Agilent, USA) high-performance liquid chromatography equipped with a quaternary pump, refractive index detector, and Shim-pack SCR-101N $(300 \mathrm{~mm} \mathrm{~L} . \times$ $7.9 \mathrm{~mm}$ I.D., $10 \mu \mathrm{m}$ ). The mobile phase was deionized water, degassed under vacuum in an ultrasonic bath. The flow rate was $0.7 \mathrm{~mL} \mathrm{~min}^{-1}$ at a temperature of $40^{\circ} \mathrm{C}$. The quantification was achieved by comparison with analytical curves using glucose, fructose, and sucrose standards.

\section{Determination of B complex vitamins}

Samples were submitted to successive hydrolysis with hydrochloric acid and enzyme hydrolysis using diastase following a procedure described by Viñas et al. (2003).

\section{Phenolic acid compound profile}

Phenolic acids were extracted and determined according to Kim et al. (2006).

\section{Diet animal materials}

The ingredients used for the preparation of the diet given to the animals were purchased from the local market. These items were corn starch, sucrose, and soybean oil purchased fresh from specialized stores. Casein was obtained from SiscoResearch Laboratories PVT, LTD, India. Salts and vitamins used for the preparation of the salt and vitamin mixtures were obtained from Merck, Germany, and prepared according to (AIN 93) Philip et al. (1993).

Animals used in this experiment were Sprague-Dawley male rats, obtained from the animal house of the $\mathrm{Na}$ tional Research Centre; their body weight ranged between 90 and $110 \mathrm{~g}$. Kits used for the estimation of the analyzed parameters were obtained from Biodiagnostic, Egypt. 


\section{Design of animal experiment}

The animal experiment comprised 3 groups each of 8 rats. The 1st group (G1) was fed on the standard normal diet. The same 2nd group (G2) and 3rd (G3) were fed on a standard normal diet. The same 2nd group feed the pharmaceutical formula of zinc and vitamin A calculated according to the Institute of Medicine IOM, Food and Nutrition Board (2001) and added to rat diet. It is often prescribed to patient suffered from sexual dysfunction as a dietary supplement in the form of gelatin capsules, each contains $25 \mathrm{mg}$ of zinc, vitamin A $50000 \mathrm{u}$, and vitamin E $100 \mathrm{mg}$.

The 3rd group demonstrated wheatgrass juice by gavage, the quantity of juice calculated the zinc content in the juice, and zinc concentrations were given based on the daily dietary allowance of $11 \mathrm{mg} /$ day for male rats (Institute of Medicine IOM, Food and Nutrition Board 2001).

Animals were kept individually in stainless steel cages, standard diet and distilled water were allowed ad libitum, and the room temperature was adjusted at $25^{\circ} \mathrm{C}$. The feeding period continued for 6 weeks. During the experimental period, the bodyweight of the animals was followed. The experimental procedure was carried out according to the Institutional Animal Ethics Community of the NRC, Egypt. At the end of the experimental period, animals fasted overnight, and in the morning, blood samples were taken from each rat by open heart puncture under light ether anesthesia. Blood samples were left to clot at room temperature and then centrifuged at 3500 rpm and serum was separated. The serum samples were kept in the deep freeze at $-20{ }^{\circ} \mathrm{C}$ till analysis.

Aspartate aminotransferase (AST), alanine aminotransferase (ALT), total bilirubin, and albumin were estimated according to Reitman and Frankel (1957), Malloy and Evelyn (1937), and Bartholomev and Delany (1966). Urea, creatinine, and uric acid were determined according to Fawcett and Soctt (1960), Bartles et al. (1972), and Carroll et al. (1971), respectively.

Malondialdehyde was assessed in blood serum according to the procedure of Satoh (1979), superoxide dismutase (SOD) determination was based on the method developed by McCord and Fridovich (1969), and glutathione peroxidase $(\mathrm{GPx})$, catalase (CAT), and reduced glutathione (GSH) were determined according to the methods of Weinhold et al. (1990), Aebi (1984), and Ellman (1959), respectively. The total cholesterol was evaluated by the technique described by Allain et al. (1974), serum triglycerides were determined according to Fossati and Prencipe (1982), LDL-ch was assessed according to Levy (1981), and HDL-ch was evaluated according to Burstein (1970).

The levels of hormones were evaluated with detection kit according to the manufacturer's instructions using ELISA technique: AFP, TSH, FSH, LH, E2, and
Testosterone using ELISA technique purchased from Immunosec Corporation., USA, and Elisa Kit for Testosterone Testing in Rats and Mice by Rocky Mountain Diagnostics Inc.

\section{Histopathological examination}

After blood collection, all rats were rapidly sacrificed and the testes of each animal were dissected, and a portion of it was preserved in $10 \%$ buffered neutral formalin and paraffin-embedded. Four sections (5 microns in thickness) were taken from each test tissue, each section being at a distance at least $500 \mu$ from the proceeding one section was stained with hematoxylin-eosin, and the slides were examined with a light microscope under $\times 20$ magnification. Randomly selected fields were evaluated for cellular and tubular structures. Degeneration in epithelium and interstitial spaces were also noted according to Ross et al. (1989).

\section{Statistical analysis}

All studied data were statistically analyzed using Co-Stat 6.303 Software Computer Program 2004 hypothesis testing methods included one-way analysis of variance (ANOVA) using Duncan Test (COSTAT-C) (1988).

\section{Results \\ Physico-chemical of wheatgrass juice}

It can be observed in Table 1 the results of physicochemical parameters of $\mathrm{pH}$, total soluble solids (TSS, ${ }^{\circ} \mathrm{Bx}$ or \%), titratable acidity, TSS/acidity ratio, and vitamin $\mathrm{C}$ $(\mathrm{mg} / 100 \mathrm{ml})$ in the samples obtained after the processing of wheatgrass juice. Freshly extracted of wheatgrass juice was subjected to various tests in order to determine its chemical composition.

The TSS was $5^{\circ} \mathrm{Bx}$. The total titratable acidity was cleared in terms of citric acid as the percentage on a fruit weight basis. Titratable acidity was measured as $0.00992 \%$, and the TSS/acidity ratio was found to be in wheatgrass juice of 504 . Also, the $\mathrm{pH}$ value was recorded as 6.7 as seen in Table 1 .

Results in Table 1 illustrated that the wheatgrass juice contained a good value of vitamin C $(0.360 \mathrm{mg} / 100 \mathrm{~mL}$ juice). The good ratio of vitamin $\mathrm{C}$ in wheatgrass juice

Table 1 Physico-chemical of wheatgrass juice

\begin{tabular}{ll}
\hline Physico-chemical & Wheatgrass juice \\
\hline pH & $6.7( \pm 0.03)^{* *}$ \\
TSS (\%) & $5.00( \pm 0.05)$ \\
Titratable acidity $^{*}$ & $0.00992( \pm 0.01)$ \\
TSS/acidity ratio & $504( \pm 0.06)$ \\
Vitamin C (mg/100 ml) & $0.360( \pm 0.01)$ \\
\hline
\end{tabular}

${ }^{*}$ Total or titratable acidity expressed as citric acid $(\mathrm{mg} / 100 \mathrm{~g})$

${ }^{* *} \pm$ Standard deviation $(\mathrm{SD}) / \mathrm{SQR}^{2}(n)$, where $n=3$ 
should be considered as a good source for such vitamin. These results amounted to an agreement with the results of Tung-Sun et al. (1995).

\section{Color characteristics and parameters of wheatgrass juice} Color is a major quality factor in juice products, and a part of the overall appearance, measurement directly in the juice samples with a Hunter Lab Ultra Scan revealed that color changed in some commercial juice sample (Table 2). In this case, brightness ( $L^{*}$ values) decreased, redness ( $a^{*}$ values) increased, and yellowness ( $b^{*}$ values) decreased. The results of periodically examined properties of the commercial wheatgrass are shown in Table 2.

\section{Vitamin B complex contents in wheatgrass juice}

There is no spotting on foods of current interest to increase nutrition awareness among consumers. But, wheatgrass juice can be easily found with nutritional compounds to provide convenient juices, in order to supplement vitamin in the diet and nutrition. The amount of vitamin B3 (nicotinic) in wheatgrass juice samples was $34.47 \mu \mathrm{g} / \mathrm{ml}$ (Table 3). The highest content of vitamin B3 was found in wheatgrass juice. Among all wheatgrass juice samples, vitamin B2 (riboflavin) was the lowest in wheatgrass juice $(1.28 \mu \mathrm{g} / \mathrm{ml})$. The highest content of vitamin B1 (thiamine) was present in wheatgrass juice which was $201.80 \mu \mathrm{g} / \mathrm{ml}$.

Furthermore, pyridoxine (vitamin B6) content in wheatgrass juice was $4.66 \mu \mathrm{g} / \mathrm{ml}$. However, the levels of the other two vitamins, B9 (folic) and B12 (cobalamin) differed between wheatgrass juice samples being 7.40 and $28.90 \mu \mathrm{g} / \mathrm{ml}$, respectively. From the aforementioned data, it could be concluded that investigated wheatgrass juice is considered to be rich sources of B complex vitamins and had a necessary bio-components that play a great role to protect the human body.

To overcome these limitations in the determination and extraction of B vitamins, HPLC-UV is the best

Table 2 Color characteristics and parameters of wheatgrass juice

\begin{tabular}{ll}
\hline Color characteristics & Wheatgrass juice \\
\hline L value & $21.78( \pm 0.38)$ \\
$a$ value & $-7.11( \pm 0.15)$ \\
$b$ value & $17.35( \pm 0.31)$ \\
$\Delta \mathrm{E}$ & $73.54( \pm 0.06)$ \\
$\mathrm{A}_{420 \mathrm{~nm}}$ & $0.91( \pm 0.01)$ \\
$\mathrm{A}_{400 \mathrm{~nm}}$ & $0.91( \pm 0.01)$ \\
$\mathrm{C}$ value & $18.75( \pm 0.34)$ \\
$\mathrm{H}$ value & $67.73( \pm 0.08)$ \\
B value & $35.40( \pm 0.32)$ \\
\hline
\end{tabular}

\pm Standard deviation $(\mathrm{SD}) / \mathrm{SQR}^{2}(n)$, where $n=3$
Table 3 Vitamins B complex of wheatgrass juice contents

\begin{tabular}{ll}
\hline B complex vitamins & Wheatgrass juice $(\mu \mathrm{g} / \mathrm{ml})$ \\
\hline Nicotinic acid, B3 & 34.480 \\
Thiamine, B1 & 201.80 \\
Pyridoxine, B6 & 4.660 \\
Folic acid, B9 & 7.400 \\
Riboflavin, B2 & 1.280 \\
Cyanocobalamin, B12 & 28.900
\end{tabular}

option. The accuracy of this method has been validated by using the recovery tests. Determining the concentrations of B1 (thiamine), B2 (riboflavin), B3 (nicotinamide), B6 (pyridoxine), B9 (folic acid), and B12 (cyanocobala$\mathrm{min}$ ) in fresh wheatgrass juice samples was the aim of this method. The results are shown in Table 3. For the spiked wheatgrass juice, samples had the valuable recovery ranges from $94.5-117.3 \%$. The concentrations of B1, B2, B3, B6, B9, and B12 in the wheatgrass juice samples were obtained to be $201.8,1.28,34.47,4.66,7.4$, and $28.9 \mu \mathrm{g} / \mathrm{ml}$, respectively, as seen in Table 3 .

\section{Phenolic acid compound profiles in wheatgrass juice}

The estimation of total phenolic acids quantified in this research varied for the different samples. No significant difference $(p<0.05)$ was observed for the phenolic acids identified. The major compounds were high in sinapic $(27.98 \mu \mathrm{g} / \mathrm{ml})$ and protocatechuic $(22.34 \mu \mathrm{g} / \mathrm{ml})$, followed by caffeic acid $(12.04 \mu \mathrm{g} / \mathrm{ml})$, rosmarinic $(11.32 \mu \mathrm{g} / \mathrm{ml})$, and gallic $(8.9 \mu \mathrm{g} / \mathrm{ml})$, but were low in catechin $(0.81 \mu \mathrm{g} /$ $\mathrm{ml})$, ferulic $(0.47 \mu \mathrm{g} / \mathrm{ml})$, cinnamic $(0.299 \mu \mathrm{g} / \mathrm{ml})$, vanillic $(2.17 \mu \mathrm{g} / \mathrm{ml})$, chlorogenic $(3.3 \mu \mathrm{g} / \mathrm{ml})$, p-hydroxybenzoic $(4.05 \mu \mathrm{g} / \mathrm{ml})$, and $\mathrm{p}$-coumaric acids $(3.04 \mu \mathrm{g} / \mathrm{ml})$, as seen in Table 4.

The wheatgrass juice had widely different phenolic contents as revealed in the data presented in Table 4. Total phenolics measured by the Folin-Ciocalteu assay varied 8.6-fold and 19-fold when measured by HPLC. The wheatgrass juice not only contained the highest standard of phenolic acids, but also contained the largest number of individual phenolic compounds; 24 were identified, with 11 being present in concentrations of > $1 \mu \mathrm{g} / \mathrm{ml}$ (Table 4).

\section{Glucose, fructose, and sucrose analysis by HPLC in wheatgrass juice}

From the result represented in Table 5, it can be defined that HPLC is more accurate in the determination of glucose, fructose, and other sugars; furthermore, it gives a direct fast reading because it is a computerized feeding system. Using peak areas, a linear regression line was drawn for each sugar (glucose and fructose). The content of total sugar in juices is essentially made up of glucose, fructose, and sucrose (saccharose). Contents of 
Table 4 Phenolic acid compound profiles in wheatgrass juice

\begin{tabular}{ll}
\hline Phenolic compounds & Wheatgrass juice $(\mu \mathrm{g} / \mathrm{ml})$ \\
\hline Gallic & 8.942794 \\
Protocatechuic & 22.34275 \\
p-hydroxybenzoic & 4.051335 \\
Gentisic & 1.749315 \\
Catechin & 0.808809 \\
Chlorogenic & 3.298519 \\
Caffeic & 12.0373 \\
Syringic & 0.582461 \\
Vanillic & 2.166147 \\
Scopoletin & 0.628308 \\
Ferulic & 0.468136 \\
Sinapic & 27.98077 \\
Rutin & 6.061411 \\
p-coumaric & 3.044506 \\
Naringin & 0 \\
Hesperidin & 0 \\
Apigenin-7-glucoside & 1.851254 \\
Rosmarinic & 11.31671 \\
Cinnamic & 0.298989 \\
Luteolin & 0 \\
Naringenin & 0 \\
Apigenin & 0.226837 \\
Kaempferol & 0.339542 \\
\hline & 1.258273 \\
\hline
\end{tabular}

glucose and fructose were $17.48 \mathrm{mg} / \mathrm{ml}$ and $12.10 \mathrm{mg} / \mathrm{ml}$ in wheatgrass juice, respectively, by HPLC; glucose (Gl) to fructose $(\mathrm{Fr})$ ratios were 1.44, while according to the HPLC determination, there is no sucrose in the wheatgrass juice, as shown in Table 5. It is necessary to determine the contents of sucrose, glucose, and fructose, as well as glucose to fructose ratio in wheatgrass juice. On the basis of sucrose, glucose, and fructose contents, as well as glucose to fructose ratio, it cannot be stated whether the examined wheatgrass juice is authentic or adulterated with other wheatgrass juice.

Table 5 Glucose, fructose, and sucrose analysis by HPLC in wheatgrass juice

\begin{tabular}{ll}
\hline Sugar contents & Wheatgrass juice $(\mathrm{mg} / \mathrm{ml})$ \\
\hline Glucose $(\mathrm{Gl})$ & 17.48 \\
Fructose $(\mathrm{Fr})$ & 12.10 \\
Sucrose $(\mathrm{Suc})$ & 0 \\
Gl to Fr ratio & 1.44 \\
\hline
\end{tabular}

\section{Biological and biochemical evaluation}

It is clear in Table 6 that the liver and kidney functions are in normal level in all experimental rats, this vital organs such as the liver and kidney that describes the toxicity or the safety of the WGJ in which the values of AST $27.88 \pm 2.10,22.50 \pm 4.93$, and $23.25 \pm 4.71 \mu / \mathrm{ml}$ in G1, G2, and G3, respectively, were improved than the normal control (G1). We observed also no differences between the results of total bilirubin and albumin $0.58 \pm 0.19$ and $0.60 \pm 0.17 \mu / \mathrm{ml} ; 0.55 \pm 0.16$ and $3.78 \pm 0.24 ;$ and $3.74 \pm$ 0.17 and $3.59 \pm 0.21 \mathrm{~g} / \mathrm{dl}$, respectively.

Table 7 presented the parameters of lipid in the blood of rats that the lowest value of mean $\pm \mathrm{SD}$ of triglycerides, total cholesterol, and LDL cholesterol in G3 amounted to $105.00 \pm 10.22,83.75 \pm 13.02$, and $95.00 \pm$ $10.33 \mathrm{mg} / \mathrm{dl}$, respectively.

As observed in Table 8, the increased in anti-oxidative enzyme value mean \pm SD of superoxide dismutase (SOD) as well glutathione peroxidase (GPx) reduced the glutathione (GSH) and catalase (Cat) $27.88 \pm 3.14 \mu / \mathrm{mg}$, $163.75 \pm 10.61 \mu / \mathrm{mg}, 181.25 \pm 10.61 \mathrm{mmol} / \mathrm{g}$, and $38.63 \pm$ $2.67 \mathrm{U} / \mathrm{mg}$, respectively.

On the other hand, wheatgrass contain many vitamins recorded in Table 1 with vitamin $C$ value $0.358 \mathrm{mg} / 100$ $\mathrm{ml}$ and in Table 3 with vitamin B12 value $28.89 \mu \mathrm{g} / \mathrm{ml}$ acts as an antioxidant, reduces oxidative stress, and also delays aging of cells in the body that causes much illness such as brain and heart problems. Many of the studies showed that the water extracts of wheatgrass as WGJ are a good source of antioxidants. Such wheatgrass juice extracts antioxidant more potential and can be used as a dietary source for antioxidant nutrients such as polyphenols as showed in Table 4, gallic acid with an altitude score of $8.943 \mu \mathrm{g} / \mathrm{ml}$, and flavonoids (Mujoriya et al. 2012).

Meanwhile, the results of sexual hormones from Table 9 indicated elevation in testosterone hormone mean \pm SD value $2.90 \pm 0.26 \mathrm{ng} / \mathrm{ml}$ than normal negative control value $2.78 \pm 0.23 \mathrm{ng} / \mathrm{ml}$ and pharmaceutical formula positive control value $2.04 \pm 0.40 \mathrm{ng} / \mathrm{ml}$, but follicle-stimulating hormone (FSH) decrease in mean \pm SD value $1.44 \pm 0.28 \mathrm{IU} / \mathrm{L}$ less than values $1.45 \pm 0.24$ and $1.65 \pm 0.23 \mathrm{IU} / \mathrm{L}$ respectively.

\section{Histopathological of testicular tissue}

Figure 1 revealed a normal histological appearance in G1, G2, and G3 of the seminiferous tubules, germ cells with sperm formation, and interstitial Leydig cells. The testes from the groups are noticed with apparently normal seminiferous tubules $(H \& E \times 200)$, and spermatogenesis is extremely regular and highly efficient such that in the normal adult rat ( $>10$ weeks old), there are very few degenerating or depleted germ cells. But in G3, there were no degenerating, depleting, or increasing germ cells compared with G1 and G2. 
Table 6 Liver and kidney functions in rats' experimental animals

\begin{tabular}{llllllll}
\hline Parameter groups & AST $(\mu / \mathrm{ml})$ & ALT $(\mu / \mathrm{ml})$ & T. bilirubin $(\mu / \mathrm{ml})$ & Albumin $(\mathrm{g} / \mathrm{dl})$ & Urea $(\mathrm{mg} / \mathrm{dl})$ & Createnine $(\mathrm{mg} / \mathrm{dl})$ & Uric acid $(\mathrm{mg} / \mathrm{dl})$ \\
\hline G1 (-ve control) & $27.88 \pm 2.10$ & $29.50 \pm 4.24$ & $0.58 \pm 0.19$ & $3.78 \pm 0.24$ & $47.75 \pm 7.40$ & $0.48 \pm 0.07$ & $2.41 \pm 0.26$ \\
G2 (+ve control) & $22.50 \pm 4.93$ & $19.88 \pm 3.40$ & $0.60 \pm 0.17$ & $3.74 \pm 0.17$ & $43.75 \pm 3.49$ & $0.44 \pm 0.04$ & $2.45 \pm 0.16$ \\
G3 (WGJ) & $23.25 \pm 4.71$ & $22.25 \pm 3.28$ & $0.55 \pm 0.16$ & $3.59 \pm 0.21$ & $45.38 \pm 7.76$ & $0.48 \pm 0.07$ & $2.63 \pm 0.21$ \\
\hline
\end{tabular}

All data are presented as means \pm SD. Values with different superscript letters are significantly different at $p<0.05$

\section{Discussion}

Exactly, results revealed the total soluble solid (TSS), the total titratable acidity was cleared in terms of citric acid as percentage on fresh fruit weight basis, TSS/acidity ratio was found to be in wheatgrass juice, and the $\mathrm{pH}$ are in line with the findings of Ashoke et al., Srivastava et al., and Stamp and Labuza (Rathod et al. 2011; Ingle et al. 1981; Srivastava and Rajput 2003; Rajput et al. 2004). The decline in the total titratable acidity should lead to elevate the total sugar content of the fruits. At the time of maturity, fruits will be having a higher amount of titratable acidity, but as the fruits advance towards ripening, the acid content will decrease. These results are in line with the findings of Ingle et al. (1981), who observed a decrease in acidity during the ripening of sapota fruits.

In this study, the $L^{*}$ value (21.78 as a lightness index), $a^{*}$ value ( -7.11 as a redness index), $b^{* * *}$ values (17.35 as a yellowness index), $H^{*}$ (67.73), $C^{*}$ (18.75), browning index (35.40, BI), $\Delta \mathrm{E}$ (73.54), and A420 nm (0.91) as non-enzymatic browning according to Stamp and Labuza 1983 and Birk et al. 1998 were statistically significant $(p<0.01)$ and were found in fresh wheatgrass juice. These results are in line with the findings of Eissa et al. (2018).

The family of water-soluble vitamins (WSVs) comprises nine vitamins, for example, thiamine (vitamin B1) and riboflavin (vitamin B2) (Heudi 2012; Nohr and Biesalski 2009). As a result of the crucial role that vitamins play an optimum role in disease prevention and as therapeutic aids, many dietary supplements (also known as nutrition or food supplements) are available (Heudi 2012). Samples of WGJ were prepared as a procedure specified above "Sample Preparation." Solid-phase extraction procedure allowed extracting all sex vitamins (water-soluble B1, B2, B3, B6, B9, and B12 as well as vitamin $C$ ), which were present in the juices. Table 1 shows a chromatogram example of wheatgrass juice extract. The presence of analytes, in particular with real samples, was confirmed by comparing the absorption spectra in the range of $200-600 \mathrm{~nm}$ and adding standard solutions. Signals without labels are derived from the matrix (Płonka et al. 2012). The B vitamins are important nutrients that support carbohydrate metabolism, promote immune system function, and induce cell growth (Adejumo 2012).

Furthermore, it is worth noting that the major phenolic compound concentration was up to three times higher. This fact could lead to an increase in juice astringency and color, as well as in juice aroma. The findings of these last acids are in accordance with those mentioned by other authors (Stalmach et al. 2011; dos Santos Lima et al. 2015); however, the phenolic acid values obtained here were closely the same in the literature. Phenolic acids like naringin, naringenin, luteolin, and hesperidin were not detected in wheatgrass juice, as seen in Table 4.

In the majority of native fruit juices, the content of saccharides is limited only to glucose, fructose, and sucrose. Contents of these sugars as well as glucose to fructose ratios are different for different juices; hence, they can be the indicators of their authenticity. These parameters are compared with standards, e.g., those specified in the Code of Practice. Deviations from accepted norms are the indicators of non-declared juice addition (Stój and Targoñski 2005). Kallio et al. (2000) determined higher concentrations of glucose in juices of different strawberry varieties-from $18.9 \mathrm{~g} / \mathrm{L}$ in the juice of Senga VP cv. in 1998 to $45.2 \mathrm{~g} / \mathrm{L}$ in the juice of Polka cv. in 1997. In juices of Senga cv., Kallio et al. (2000) found from 18.9 to $32.2 \mathrm{~g} / \mathrm{L}$ of glucose. The average content of fructose in raspberry juice of Canby cv. was significantly higher $(28.51 \mathrm{~g} / \mathrm{L})$ than the average contents of fructose in juices of Beskid $(24.28 \mathrm{~g} / \mathrm{L})$ and Malling Seedling cv. $(22.44 \mathrm{~g} / \mathrm{L})$. Other authors found greater ranges of fructose concentrations in raspberry juices. Durst et al.

Table 7 The lipid profile of rat's blood serum

\begin{tabular}{lllll}
\hline Parameters groups & Total cholesterol $(\mathrm{mg} / \mathrm{dl})$ & Triglycerides $(\mathrm{mg} / \mathrm{dl})$ & $\mathrm{HDL}$ cholesterol $(\mathrm{mg} / \mathrm{dl})$ & $\mathrm{LDL}$ cholesterol $(\mathrm{mg} / \mathrm{dl})$ \\
\hline G1 (-ve control) & $110.00 \pm 13.63$ & $111.25 \pm 22.32$ & $26.00 \pm 2.27$ & $61.75 \pm 11.11$ \\
G2 (+ve control) & $106.25 \pm 10.61$ & $91.88 \pm 12.52$ & $28.75 \pm 2.76$ & $59.13 \pm 9.06$ \\
G3 (WGJ) & $95.00 \pm 10.33$ & $83.75 \pm 13.02$ & $23.38 \pm 2.67$ & $105.00 \pm 10.22$ \\
\hline
\end{tabular}

All data are presented as means \pm SD 
Table 8 The assessment oxidative enzyme of rats' blood

\begin{tabular}{llllll}
\hline Parameters groups & SOD $(\mu / \mathrm{ml})$ & GPx $(\mu / \mathrm{ml})$ & GSH $(\mathrm{mmol} / \mathrm{ml})$ & $\mathrm{MD}(\mathrm{mmol} / \mathrm{ml})$ & Cat. $(\mathrm{U} / \mathrm{ml})$ \\
\hline G1 (-ve control) & $21.50 \pm 3.46$ & $153.75 \pm 12.46$ & $26.00 \pm 2.67$ & $161.25 \pm 22.00$ & $37.88 \pm 4.67$ \\
G2 (+ve control) & $26.88 \pm 3.40$ & $160.00 \pm 15.12$ & $29.38 \pm 4.84$ & $171.25 \pm 12.46$ & $39.00 \pm 3.12$ \\
G3 (WGJ) & $27.88 \pm 3.14$ & $163.75 \pm 10.61$ & $29.50 \pm 2.67$ & $168.75 \pm 14.08$ & $38.63 \pm 2.67$ \\
\hline
\end{tabular}

All data are presented as means $\pm S D$

(1995) reported on the fructose content ranging from $6.391 \mathrm{~g} / \mathrm{L}$ in the juice of meeker $\mathrm{cv}$. to $37.047 \mathrm{~g} / \mathrm{L}$ in the juice of Heritage cv.

Green Blood Therapy is the term that is called "green blood" of wheatgrass which normally has phytochemical pigment chlorophyll content which accounts for about $70 \%$ of its total chemical constituents (Swati et al. 2010) and the use of WGJ to cure many multiple diseases. In addition, wheatgrass is called as the green blood which is a medicinal herb; therefore, wheatgrass like all green plants, due to the high score of chlorophyll content, is high in oxygen content, more amount of vitamins (especially vitamin E), and antioxidants too. And also, the WGJ contains nearly all the nutrients which the body needs and is to be considered a complete food.

The normal liver function recorded in all groups of experimental rats with respect to the normal hepatocytes without hepatic necrosis showed also, in the same findings, the normal kidney function. Wheatgrass juice cleanses the toxins and pollutants of the body, by many enzymes, and amino acids play an essential role as a natural cleanser to detoxify the liver and to eliminate toxic heavy metals from the body's bloodstream, rid the waste matter out of the body, and delay the aging process (Sareen et al. 2014).

This study suggested that sterols found in WGJ might have reduced cholesterol absorption in the intestine and elevated cholesterol excretion out of the body in anti-hyperlipidemia activity of WGJ. Saponins another highly active phytochemicals considered to increase fecal cholesterol excretion (Matsui et al. 2006). Mainly, cholesterol in the intestine can arise by the diet and hepatic bile salt secretions. Further, inhibitions of cholesterol absorption from the intestine also decrease the delivery of cholesterol to the liver, meaning that its potential is thereby to reduce serum as well as hepatic cholesterol. This action leads to accelerate the rat in the absorption of LDL from plasma via LDL receptors and increase the clearance of plasma cholesterol (Patel 2004; Hala et al. 2014).

Recently, it was documented that during germination, some biologically active phytochemicals were synthesized in the wheat sprouts (Calzuola et al. 2004). Wheat sprouts accomplished the maximum antioxidant potentials and antioxidant enzyme superoxide dismutase (SOD) after 7 days of plant growth. In addition to this, wheat sprout extracts such as WGJ were found to be anti-mutagenic in the Ames test (Peryt et al. 1992) capable of inhibiting oxidative DNA damage (Falcioni et al. 2002) and responsible for metabolic deactivation of carcinogens.

Eventually, various forms of physical and psychological stress are believed to reduce sexual functions. Many studies have examined the relationship between stress and sexual potency in male rats (Stefan et al. 2011). These reports showed that the chronic psychological and physical stress induce erectile dysfunction, which results from neurotransmission changes in various erectile response pathways and reduced blood flow in genital organs (Vijay Prasad et al. 2012). Oxidative stress has frequently been involved as a leading cause of male factor infertility too (Stefan et al. 2011).

As expected, from previous parameters, the testicular membranes are rich in polyunsaturated fatty acids, and thus, mainly the cells are susceptible to peroxidation injury (Stefan et al. 2011). The WGJ is the richest source of natural antioxidants that mainly protect the testicular cells of oxidation deleterious stress and permit the test cells in the best normal function. Also, oral zinc dose given in natural juice form (WGJ) and in a pharmaceutical formula is a rich source of zinc $(93 \mathrm{mg}$ per100 ml) as founded by Eissa et al. (2018) because zinc is important for normal growth and regeneration, testicular

Table 9 The evaluation of sexual hormone in rats' blood serum

\begin{tabular}{lllllll}
\hline Parameters groups & FSH (IU/L) & LH (IU/L) & TSH () & Prog. $(\mathrm{ng} / \mathrm{ml})$ & Testo $(\mathrm{ng} / \mathrm{ml})$ & E2 $(\mathrm{pg} / \mathrm{ml})$ \\
\hline G1 (-ve control) & $1.65 \pm 0.23$ & $0.89 \pm 0.12$ & $0.48 \pm 0.10$ & $0.31 \pm 0.05$ & $2.78 \pm 0.23$ & $12.15 \pm 2.31$ \\
G2 (+ve control) & $1.45 \pm 0.24$ & $1.29 \pm 0.33$ & $0.64 \pm 0.17$ & $0.42 \pm 0.05$ & $2.04 \pm 0.40$ & $15.73 \pm 0.84$ \\
G3 (WGJ) & $1.44 \pm 0.28$ & $0.74 \pm 0.08$ & $0.54 \pm 0.12$ & $0.34 \pm 0.06$ & $2.90 \pm 0.26$ & $14.93 \pm 0.73$ \\
\hline
\end{tabular}

All data are presented as means \pm SD

LH luteinizing hormone, FSH follicle-stimulating hormone, Prog progesterone, E2 estradiol \& test testosterone 


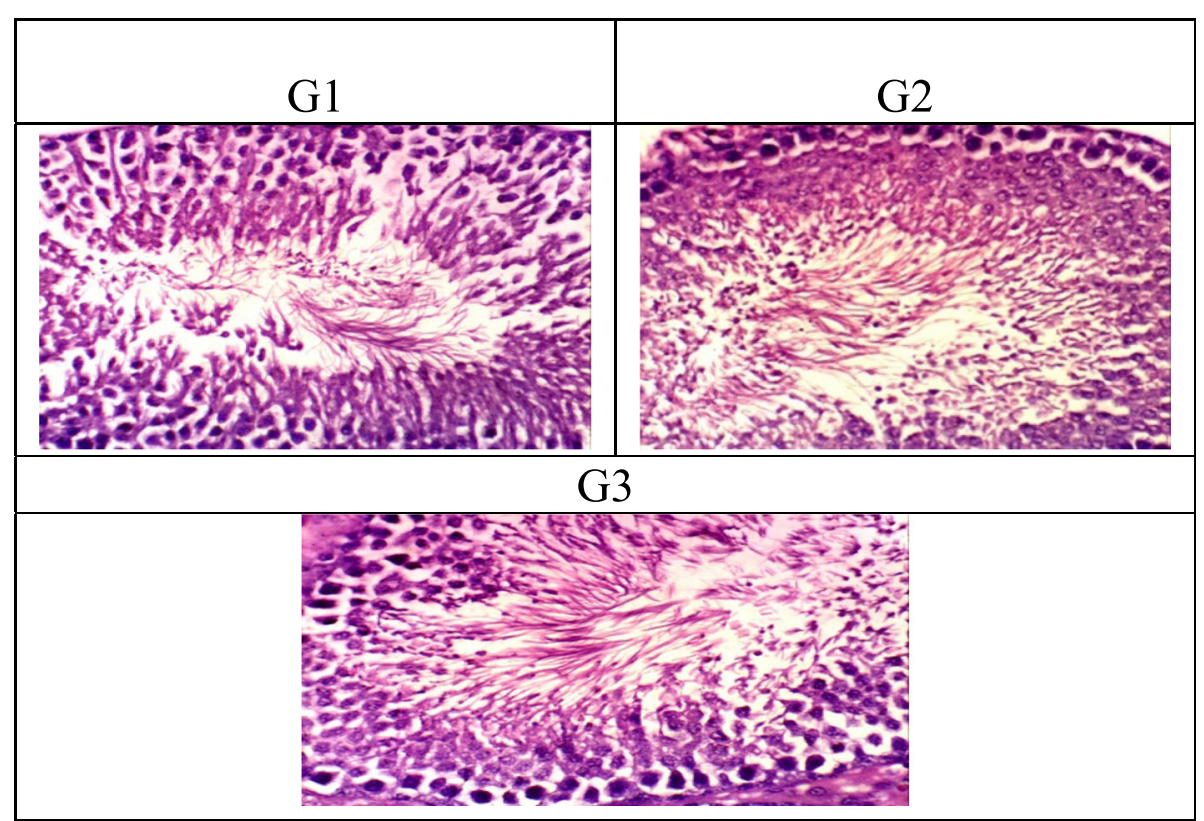

Fig. 1 Testes from G1, G2, and G3

maturation, neurological function, wound healing process, and immune-competence (European Commission 2003).

It may due to the negative feedback effect of testosterone on the hypothalamus which in turn causes reduction in the secretion of FSH and LH by the gonads of the anterior pituitary gland (Guyton and Hall's 2006). Gonadotropin production is under the feedback control of sex hormones (Ganong 2003). It exists under physiological status in the divalent. The structure and function of cell membranes are also affected by zinc; hence, the loss of zinc from biological membranes can elevate their susceptibility to oxidative damage and impair their function (O'Dell 2000).

Wheatgrass with chlorophyll content is primarily a phytonutrient, which is rich in macro- and micronutrients alongside and, at the same time, contain enzymes that work mutually for strong immunity. It builds up protection from diseases and detoxification of the body, and because of its alkaline properties, it has good properties for urinal problems. WGJ returns fertility and improves youthfulness because of the high magnesium content in the chlorophyll chemical structure which builds enzymes that get back sex hormones. Wheatgrass helps to detoxify and clean the body by fracturing impacted substances in the colon (Duke 1983).

\section{Conclusion}

The prepared wheatgrass juices as a natural juice to improve a healthy life additionally resulted in a highly acceptable and nutritious ready-to-drink juice, as well as a good level of vitamin $\mathrm{C}$. The highest content of vitamin B1 (thiamine), B3 (nicotinic acid), and B12 was found in wheatgrass juice. Meanwhile, the major compounds of phenolic compounds in wheatgrass juice were high in sinapic and protocatechuic, followed by caffeic acid, rosmarinic, and gallic. Contents of glucose and fructose were high, while according to the HPLC determination, there is no sucrose in the wheatgrass juice. Due to its high content of bioactive compounds, it could be recommended for consumption as a fresh juice blend to elevate fertility and promote youthfulness. This juice meets the changes in the present-day consumers' lifestyle which has led to a vital change in the marketing trends of the food sector. It also highly encourages the consumption of juices for their importance for micronutrient and macronutrient and their health benefits as recommended by FAO/WHO Expert Consultation on juice.

\section{Abbreviation}

ALT: Alanine aminotransferase; AST: Aspartate aminotransferase; B1: Thiamine; B12: Cyanocobalamin; B2: Riboflavin; B3: Nicotinamide; B6: Pyridoxine; B9: Folic acid; CAT: Catalase; E2: Estradiol \& test testosterone; FSH: Folliclestimulating hormone; GPX: Glutathione peroxidase; GSH: Reduced glutathione; HPLC: High-performance liquid chromatography; IOM: Institute of Medicine; LH: Luteinizing hormone; Prog: Progesterone; SD: Standard deviation; SOD: Superoxide dismutase; TSS: Total soluble solids; WG: Folliclestimulating hormone (FSH) \wheatgrass; WGJ: Wheatgrass juice; WSVs: Watersoluble vitamins

\section{Acknowledgements}

The authors are grateful and thankful to the projects' department and animal house, National Research Centre, for their help and facilities which supported us to manage this research. 


\section{Significance statement}

The study represented novel properties of WGJ as well as fertility and promotes youthfulness that can be beneficial to sexual dysfunction in males that may occur in complications with diabetes syndrome or other diseases. Meanwhile, many disease treatments are important topics on utilizing and exploring combinations of WGJ with a diabetic diet system or extracted in a pharmaceutical formulation that will be potent in sexual dysfunction in males' drugs.

\section{Authors' contributions}

SSM made the study design, proceeded the rat experiments and biochemical analysis, collected and analyzed the data statistically, and in the end drafted the manuscript. HAE contributed to the preparation of the juice technology and in writing the manuscript. AMSH participated in the HPLC studies and biochemical investigations and helped in the writing and submission of the manuscript. Also, he participated in the sample collection, data collection, and analysis. This work was carried out in collaboration with all authors. This manuscript was revised and approved by all authors.

\section{Funding}

This work was supported by the Food Industries \& Nutrition Division, National Research Centre.

\section{Availability of data and materials}

All data generated or analyzed during this study already exist in this published article.

\section{Ethics approval and consent to participate}

The healthy male rats (albino Wistar) used were procured from the animal house of National Research Centre, Cairo, Egypt.

\section{Consent for publication}

Not applicable.

\section{Competing interests}

The authors declare that they have no competing interests.

\section{Author details}

${ }^{1}$ Foot Technology Department, National Research Centre, 33 El Bohouth St. Cairo 12622, Egypt. ${ }^{2}$ Nutrition and Food Science Department, National Research Centre, 33 El Bohouth St., Cairo 12622, Egypt.

Received: 21 March 2019 Accepted: 16 January 2020

Published online: 19 February 2020

\section{References}

A.O.A.C (2006) Official methods of analysis, vitamins and other nutrients. Ascorbic acid in vitamin preparation and juices. Chapter 45, No. 967.21, pp 16-17

Adejumo BA (2012) Effect of drying methods and pretreatment on some physicochemical quality attributes of tomato powder. Int I Innovative Res Dev 1(11):51-58

Aebi H (1984) Catalase in vitro. Methods Enzymol 105:121-126

Allain CC, Poon LS, Chan CS, Richmoud W, Fu PC (1974) Enzymatic determination of total serum cholesterol. Clin.Chem 20:470-475

Bartholomev, R.J.; Delany, A. (1966). Hepatoprotective effect of Spirulina lonar on paracetamol induced liver damage. Proc Aust. Assoc .Biochemists., 1: 214.

Bartles H, Bohmer M, Heirli C (1972) Serum creatinine determination without protein precipitation. Clin Chem Acta 37:193-197

Birk E, Mannheim C, Saguy I (1998) A rapid method to monitor quality of apple juice during thermal processing. Lebensm.-Wiss.u.-Technol 31:612-616

Burstein MA (1970) Fully enzymatic colorimetric determination of HDL cholesterol in the serum. Lipid Res 11:583-595

Calzuola I, Valeria M, Gianfranceschi GL (2004) Synthesis of antioxidants in wheat sprouts. J Agric Food Chem 52:5201-5206

Carroll JJ, Roberta Douglass HC, Babson AL (1971) A simplified alkaline phosphotungstate assay for uric acid in serum. Clin Chem 17:158-160

COSTAT-C (1988) COSTAT-C, a microcomputer program for the design, arrangement and analysis of agronomic research. Michigan State University, East Lansing, p 138
DeVogel J, Denize SML, Jonker TM, Katan MB, van der Meer R (2005) Natural chlorophyll but not chlorophyllin prevents heme-induced cytotoxic and hyperproliferative effect in rat colon. J Nutr 135:1995-1900

dos Santos Lima M, da Conceição Prudêncio Dutra M, Toaldo IM, Corrêa LC, Pereira GE, de Oliveira D, Bordignon-Luiz MT, Ninow JL (2015) Phenolic compounds, organic acids and antioxidant activity of grape juices produced in industrial scale by different processes of maceration. Food Chem 188:384-392

James A. Duke. (1983) The Handbook of Energy Crops, The National Agricultural Library is one of four national libraries of the United States, with locations in Beltsville, Maryland and Washington, D.C. It houses one of the world's largest and most access.

Durairaj V, Hoda M, Shakya G, Baby SPP, Rajagopalan R (2014) Phytochemical screening and analysis of antioxidant properties of aqueous extract of wheat grass. Asian Pa J Trop Med 7:5398-5404

Durst RW, Wrolstad RE, Krueger DA (1995) Sugar, nonvolatile acid, 13C/12C ratio and mineral analysis for determination of the authenticity and quality of red raspberry juice composition. J Assoc Off Anal Chem 78:1195-1204

Eissa HA, Yaseen AA, Bareh GF, Ibrahim WA, Mansour AF (2018) Enhancing aroma flavor, bio-active constituents and quality attributes of cantaloupe juice supplementing with wheat grass juice. J Biol Sci 18(1):1-12

Ellman GL (1959) Tissue sulfhydryl groups. Arch Biochem Biophys 82:70-77

European Commission (2003) Opinion of the scientific committee on food on the tolerable upper intake of zinc. Health and Consumer Protection Directorate General. Directorate CScientific Opinions. Scientific Committee on Food SCF/CS/NUT/UPPLEV/62 Final.

Falcioni G, Fedeli D, Tiano L, Calzuola I, Mancinalli L andGianfranceschi G. (2002) Antioxidant activity of wheat sprouts extract in vitro: inhibition of DNA oxidative damage. Journal of Food Sci 67(8):2918-2922

Fawcett JK, Soctt JE (1960) A rapid and precise method for the determination of urea. J Clin Pathol 13:156-159

Fernandes Glaura SA, Fernandez CDB, Campos KE, Damasceno DC, AnselmoFranci JA, Kempinas WDG (2011) Vitamin C partially attenuates male reproductive deficits in hyperglycemic rats. Reprod Biol Endocrinol 9(100): $1-9$

Ferruzzia MG, Blakesleeb J (2007) Digestion, absorption and cancer preventive activity of dietary chlorophyll derivatives. Nutr Res 27:1-12

Fossati P, Prencipe I (1982) Serum triglyceride determination calorimetrically using an enzyme that produce hydrogen peroxide. Clin Chem 28:2077-2080

Ganong WF (2003) Review of medical physiology, 21st edn. Lange Medical Books/Mcgraw-Hill Medical publishing, New York

Grunewald J (2009) Novel botanical ingredients for beverages. Clin Derm 27: $210-216$

Guyton and Hall (2006) Textbook of Medical Physiology. Thirteenth edition. 2016 John E. Hall Elsevier, Hardcover. \$124.99. ISBN: 978-1-4557-7005-2. Published online 2017 Nov 9. https://doi.org/10.4103/sni.sni_327_17.

Hala MFED, Mohamed SS, El-Messery TM (2014) Role of the functional food (pomegranate-yoghourt) as hepatoprotective effect on liver injured rats. Int J Curr Microbiol App Sci 3(8):185-196

Heudi O (2012) Methods for the simultaneous quantitative analysis of watersoluble vitamins in food products. In: Nollet LML, Toldrá F (eds) Handbook of analysis of active compounds in functional foods, 1st edn. CRC Press, Boca Raton, pp 149-165

Hunter RS (1975) Scales for measurements of color differences. In: Wiley J (ed) Measurement for Appearances. Inter science, New York, p 133

Ingle GS, Khedkar DM, Dabhade RS (1981) Ripening studies in sapota fruit (Achras sapota I.). Indian Food Packer 35:42-45

Institute of Medicine IOM, Food and Nutrition Board (2001) Dietary reference intakes: vitamin A, vitamin K, arsenic, boron, chromium, copper, iodine, iron, manganese, molybdenum, nickel, silicon, vanadium and zinc. National Academy Press.WashingtonDC.IUNA (Irish Universities Nutrition Alliance) (2001).The North/South Ireland FoodConsumption Survey - special issue. Pub Health Nutr 4

Kallio H, Hakala M, Pelkkikangas AM, Lapveteläinen A (2000) Sugars and acids of strawberry varieties. Eur Food Res Technol 212:81-85

Kim KH, Tsao R, Yang R, Cui SW (2006) Phenolic acid profiles and antioxidant activities of wheat bran extracts and the effect of hydrolysis conditions. Food Chem 95:466-473

Levy AL (1981) A fully enzymatic colorimetric determination of LDL cholesterol in the serum. Clin Chem 27:653-662

Malloy HT, Evelyn KA (1937) The determination of bilirubin with the photoelectric colorimeter. J Biol Chem 119:481 
Matsui Y, Kumagai H, Masuda H (2006) Nihon Shokuhin Kagaku K ôgakkai. Food Sci Technol Res 12:50

McCord JM, Fridovich I (1969) Superoxide dismutase: an enzymatic function for erythrocuprein (hemocuprein). J Biol Chem 244:6049-6055

Mujoriya R, Patel S, Balaghat, dis. Balaghat (2012) A study on wheat grass and its nutritional value. Food Sci Qual Manag 2 www.iiste.org. ISSN 2224-6088 (Paper) ISSN 2225-0557 (Online)

Nohr D, Biesalski HK (2009) Vitamins in milk and dairy products: B-group vitamins. In: McSweeney PLH, Fox PF (eds) Advanced dairy chemistry, volume 3: lactose, water, salts and minor constituents. Springer Science + Business Media, LLC., New York, pp 591-630

O'Dell BL (2000) Role of zinc in plasma membrane function. J Nutr 130(5S Suppl): $14325-14365$

Palou E, Lopez-Malo A, Barbosa-Canovas G, Chanes-Welti J, Swanson W (1999) Polyphenoloxidase and colour of blanched and high hydrostatic pressure treated banana puree. J Food Sci 64(1):42-45

Pannu JS, Kapoor RK (2015) The green blood wheatgrass juice, a health tonic having antibacterial potential, Department of Microbiology, M.D University, Rohtak, 124001(Haryana), India. World J Pharm Res 4(3):46-54 Research Article, ISSN 2277- 7105

Patel SB (2004) Ezetimibe: a novel cholesterol-lowering agent that highlights novel physiologic pathways. Curr Cardiol Rep 6:439-442

Peryt B, Szymczy KT, Lesca P (1992) Mechanism ofantimutagenicity of wheat sprout extracts. Mutat Res 269:201-205

Philip G., Reeves Forrest H., Nielsen George, C., and Fahey JR. (1993). AIN-93 purified diets for laboratory rodents: final report of American Institute of Nutrition Ad Hoc Writing Committee on the Reformuation of the AIN-76A rodent diet. American Institute of Nutrition, 0022-3166/93 p. 19391951

Płonka J, Toczek A, Tomczyk V (2012) Multivitamin analysis of fruits, fruitvegetable juices, and diet supplements. Food Anal Methods 5:1167-1176

Rajput CBS, Srivastava KK, Srivastava AK (2004) Malviya Carambola 1: a promising star fruit selection

Rana S, Kamboj JK, Gandhi V (2011) Living life the natural way - wheatgrass and health. Funct Foods Health Dis 1(11):444-456

Rathod A, Shoba H, Chidanand DV (2011) A study on shelf life extension of carambola fruits. Int J Sci Eng Res 2(9):1-5

Reitman S, Frankel S (1957) Determination of glutamate pyruvat transaminase and glutamate oxaloacetate transaminase. Amer J Clin Path 28:56-63

Ross MH, Reith EJ, Rombell $\sqcup$ (1989) Histology: a text and atlas, 2nd edn. Williams \& Wilkins, Battimore

Sangeetha RK, Baskaram V (2010) Carotenoid composition and retinol equivalent chenopodium albumin retinol-deficient rats. Food Chem 119:1584-1590

Sapers G, Douglas F (1987) Measurement of enzymatic browning at cut surfaces and in juice of raw apple and pear fruits. J Food Sci 52(12581262):1285

Sareen M, Baghla P, Dhaka P, Mathur E, Sobti P, Khajuria S (2014) Wheat grass-a wonder herb. Syst Rev Pharm 5(1):4

Satoh K (1979) Serum lipid peroxide in cerebrovascular disorders determined by a new colorimetric method. Clin Chem Acta 20:37-43

Srivastava KK, Rajput CBS (2003) Genetic diversity in carambola (Averrhoa carambola L.), Indian Horticulture, Oct - Dec, p 2

Stalmach A, Edwards CA, Wightman JD, Crozier A (2011) Identification of (Poly)phenolic compounds in concord grape juice and their metabolites in human plasma and urine after juice consumption. J Agric Food Chem 59: 9512-9522

Stamp J, Labuza T (1983) Kinetics of the maillard reaction between aspartame and glucose in solution at high temperatures. J Food Sci 48(543-544):547

Stefan S, Anthony K, Vaamonde D, Agarwal A (2011) Is there a link between exercise and male factor infertility? Open Reprod Sci J 3:105-113

Stój A, Targoñski Z (2005) Use of sugar content analysis for the estimation of berry juice authenticity. Pol J Food Nutr Sci 14/55(4):403-409

Swati P, Sushma D, Indira R, Alka G, Mamta D (2010) Multitude potential of wheatgrass juice (green blood): an overview. Chronicles Young Sci 1(2): $23-28$

Tung-Sun C, Siddiq M, Sinha N, Cash J (1995) Commercial pectinase and the yield and quality of Stanley plum juice. J Food Process Preserv 19:89-101

Vijay Prasad S, Ghongane BB, Nayak BB, Raul AR, Vijay Kumar AN, Mutalik MM et al (2012) An experimental study on effect of antioxidant vitamin $E$ in stress and alcohol induced changes in male fertility in albino rats. Int J Med Res Health Sci 1(1):1-6
Viñas P, López-Erroz C, Balsalobre N, Hernández-Córdoba M (2003) Reversedphase liquid chromatography on an amide stationary phase for the determination of the $B$ group vitamins in baby foods. J Chromatogr A 1007(1-2):77-84

Weinhold LC, Ahmad S, Pardini RS (1990) Insect glutathione S-transferase: a predictor of allelochemical and oxidative stress. Comp Biochem Physiol 95(B): 355-363

Wheat J, Currie J (2008) Herbal medicine for cancer patients: an evidence based review. Internet J Altern Med 5:28-30

\section{Publisher's Note}

Springer Nature remains neutral with regard to jurisdictional claims in published maps and institutional affiliations.

\section{Submit your manuscript to a SpringerOpen ${ }^{\circ}$ journal and benefit from:}

- Convenient online submission

- Rigorous peer review

- Open access: articles freely available online

- High visibility within the field

- Retaining the copyright to your article

Submit your next manuscript at $>$ springeropen.com 